\title{
SEED PRODUCTION AND SUPPORT SYSTEMS FOR AFRICAN LEAFY VEGETABLES IN THREE COMMUNITIES IN WESTERN KENYA
}

\author{
Abukutsa-Onyango Mary ${ }^{1 *}$
}

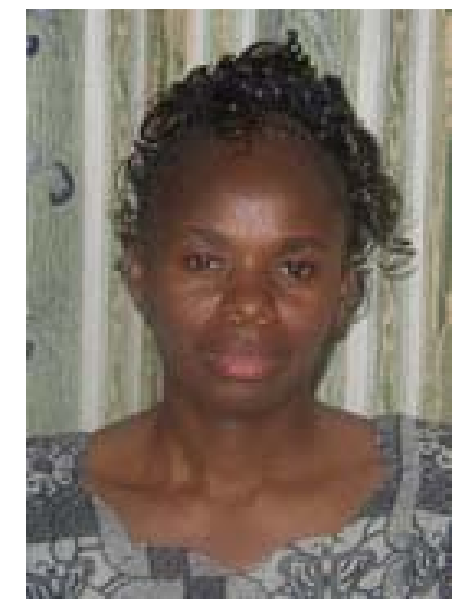

Prof. Mary Abukutsa Onyango

\footnotetext{
${ }^{1}$ Department of Botany \& Horticulture, Maseno University, Kisumu-Busia Road. P.O Box 333, 40105-Maseno, KENYA. mabukutsa@yahoo.com
} 


\section{ABSTRACT}

Communities in western Kenya have utilized several species of African Leafy Vegetables for food and valued them for their taste, nutritional qualities and medicinal properties. With increasing demand for these vegetables, there is a dire need for a formal reliable source of quality seed and need to study and develop seed support systems in communities in western Kenya.

The objectives of the study were: determine the current seed support systems; collect, evaluate and multiply germplasm; establish seed support systems; determine effect of seed treatments on seedling emergency of priority African Leafy Vegetables in three communities in western Kenya. A survey was conducted by administering structured questionnaires to 30, 20 and 30 households in the Luhya, Luo and Kisii communities, respectively between Jan 2002 and March 2003.

Germplasm collection, evaluation and multiplication of the priority African Leafy Vegetables was effected. Multiplied germplasm was used to establish a seed support system at Maseno University botanic garden and with 70 farmers in the three communities. Seed treatments for spiderplant, nightshades and jute mallow was conducted between June and August 2004. Treatments included $\mathrm{T}_{1}=$ No treatment or Control, $\mathrm{T}_{2}=$ Dipped seed in boiling water for 10 seconds, $\mathrm{T}_{3}=$ Soaked seeds in water for $24 \mathrm{hrs}$ and $\mathrm{T}_{4}=$ Soak seed in $95 \%$ acetone for 30 minutes.

Current seed support systems for African Leafy Vegetables are informal and constitute production from farmers' own fields or from the village markets. Seven African leafy vegetable species were selected from 42 accessions collected based on seed weight, germination percentage and seed moisture content and these included Cleome gynandra, Crotalaria brevidens, Crotalaria ochroleuca, Solanum scabrum, Vigna unguiculata, Amaranthus blitum and Corchorus olitorius. Seed yields of the above species ranged from $1036-1320 \mathrm{~kg} /$ ha with 1000 seed weight of 1.1 to $100 \mathrm{~g}$.

A total of 70 contact farmers in 6 districts of western Kenya were provided with seed and technical information on production and processing of seed, 13\% of whom had started producing quality seed for their use or sale. A seed support system was set up at Maseno University Botanic garden to avail seed of the seven African Leafy Vegetables to farmers in the region and beyond. Seed treatments had a significant effect on the seedling emergence of spiderplant and African nightshade but not on jute mallow. It is recommended that Agronomic, processing and utilization packages be developed for the identified species.

KEY WORDS: African Leafy Vegetables, seed systems 


\section{INTRODUCTION}

African Leafy Vegetables are important for food and as a source of income in many western Kenya communities [1]. A survey conducted in three markets in western Kenya indicated that African Leafy Vegetables contributed $10 \%$ of the income generated by commodities in the markets during the study period [1].

The most important species include spiderplant (Cleome gynandra), African nightshades (Solanum villosum and Solanum scabrum), pumpkin leaves (Cucurbita moschata), Cowpeas (Vigna unguiculata), Vegetable amaranths (Amaranthus blitum), jute mallow (Corchorus olitorius),), slenderleaf ( Crotalaria ochroleuca and Crotalaria brevidens) and African kale (Brassica carinata), representing seven botanic families Amaranthaceae, Brassicaceae, Capparaceae, Cucurbitaceae, Fabaceae, Solanaceae and Tiliaceae [1].

African Leafy Vegetables are valued by different communities in western Kenya for their taste, nutritional qualities, medicinal and culinary properties [2]. These vegetables are easily adapted to the environmental conditions they are being grown and are easy to grow and manage [3]. A market survey conducted in Kakamega municipal market and two rural (Kiboswa and Chavakali) markets indicated that African Leafy Vegetables contributed $20 \%$ of the total value of commodities traded during the study period [1].

Studies have also shown that for a very long time these vegetables were collected from the wild but as the pressure on land increased, they were domesticated and the need for quality seed set in $[3,4]$. Normally, African Leafy Vegetables are grown as a subsistence crop and only the surplus is sold to the markets while farmers prepare and preserve their own seed which in most cases is of poor quality [3]. With increasing demand for this commodity, there is a need for increased production and this call for good quality seed for increased yields to meet the demand for these vegetables particularly in urban and peri-urban areas [4].

Seed production system of spiderplant, slenderleaf and African nightshades in Kakamega district of western Kenya was found to be an informal one [2]. Farmers were found to produce and store their own seed and distribute seeds among themselves. Farmers lack adequate knowledge on how to grow and process seed optimally and there fore need to be trained on these aspects [5]. This will be a short term solution as mechanisms are put in place for formal breeding programmes for African Leafy Vegetables [2]. Some farmers in Kisii district have already been trained on seed production and processing methods with the aim of commercializing seed production of African Leafy Vegetables [6].

It has been established that proper processing of seed determines the quality of the seed for example sun-drying of spiderplant seeds was reported to improve the mean

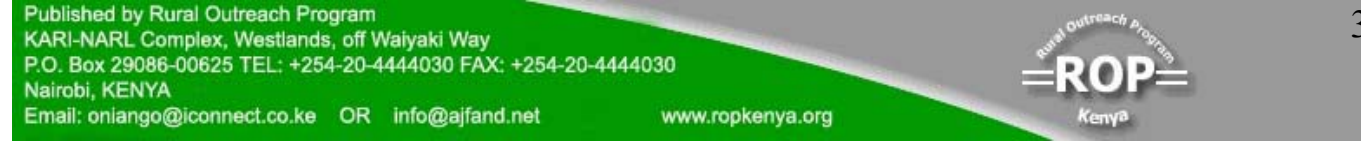


germination time, seedling vigour and overall germination percentage compared with shade dried seeds [7].

Temperature and light have been shown to have a significant influence on germination of spiderplant, where best conditions for seed germination are $20-30^{\circ} \mathrm{C}$ in darkness, spiderplant seeds are negatively photosensitive and the effects of photoinhibition increases at temperatures lower than $20^{\circ} \mathrm{C}$ and germination is also influenced by physiological maturity [8].

Other African leafy vegetable species that have shown poor germination and dormancy problems include African nightshades and jute mallow [3]. Poor germination and dormancy problems are normally attributed to the presence of growth inhibitors, the physical hardness of the seed/fruit coats and damage by insects. Slenderleaf and cowpea normally do not have problems with germination, and slenderleaf (Crotalaria brevidens) has been reported to maintain germination percentages of over $90 \%$ even after five years of seed storage [9].

Among the constraints that hinder optimal production of African Leafy Vegetables, seed quality has been the major one among others [1]. It was, therefore, essential to study the current seed support and supply systems in three communities in western Kenya and develop and suggest ways and means of improving them.

\section{OBJECTIVES}

Determine the current seed support systems of African Leafy Vegetables in three communities of western Kenya

+ Collect, evaluate and multiply germplasm of priority African Leafy Vegetables in three communities of western Kenya

* Establish seed support systems of priority African Leafy Vegetables in three communities of western Kenya

* Determine the effect of seed treatments on seedling emergency of three priority African Leafy Vegetables in three communities of western Kenya.

\section{MATERIALS AND METHODS}

\section{Current seed support and supply systems in Luhya, Luo and Kisii communities}

A survey was conducted between January 2002 and March 2003 in six districts of two provinces that represented three communities in western Kenya. The six districts included Vihiga and Butere/Mumias districts in Western Province representing the Luhya community, Kisumu and Siaya Districts in Nyanza Province representing the Luo community and Kisii and Nyamira Districts representing the Kisii Community.

From these districts, households were purposively sampled on the basis of their growing African Leafy Vegetables. A structured questionnaire was developed and administered to 80 households in the three communities as follows: Luhya

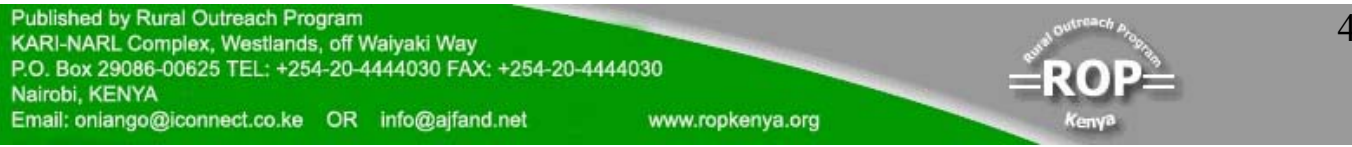




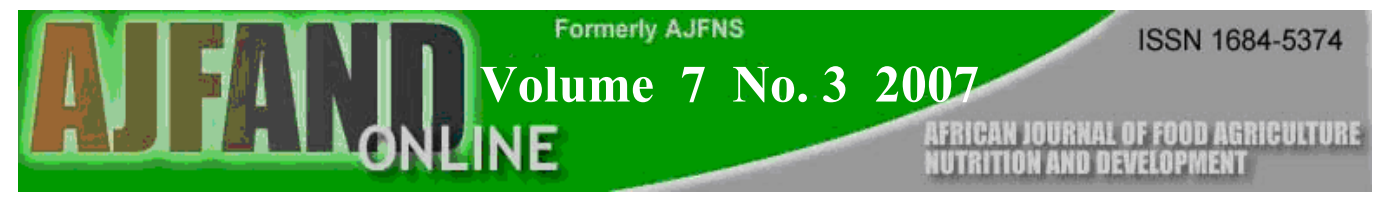

Community 30 households, Luo community 20 households and Kisii community 30 households. The total households in the three communities were 170,000, 90,000 and 140,000 households for Luhya, Luo and Kisii communities, respectively.

\section{Germplasm Collection, Evaluation and Multiplication of the collected priority African Leafy Vegetable species in Western Kenya}

Germplasm collection of Vegetable amaranths (Amaranthus blitum), Spiderplant (Cleome gynandra), Jute mallow (Corchorus olitorius), slenderleaf (Crotalaria brevidens and Crotalaria ochroleuca) African nightshade (Solanum scabrum) and Cowpeas (Vigna unguiculata) was effected during the survey and evaluated in the laboratory by weighing, determining moisture content and germination percentages of the selected accessions which were then regenerated and multiplied in the field.

Seed regeneration and multiplication of the above seven selected African Leafy Vegetable species was conducted from May to December 2003 at Maseno University botanic Garden in plots measuring $10 \mathrm{mx} 10 \mathrm{~m}$ for each vegetable. All the seven vegetables except Solanum scabrum were direct seeded by drilling in rows $30 \mathrm{~cm}$ apart then thinned to intra-row spacing of $30 \mathrm{~cm}$ at two weeks later. Solanum scabrum was first raised in the nursery then transplanted when at 4-6 leaf stage. At planting time farm yard manure at the rate of 20 tons per hectare was applied into the plots. The seeds were harvested and processed to moisture content of about $8-10 \%$ and weighed and seed yield determined.

\section{Establishment of seed support system in three communities in western Kenya}

Seed production varied with the species. The seven species were bulked, packaged in varying farmer friendly quantities of $10,20,50$ and $100 \mathrm{~g}$ in plastic bags, sealed and made available at Maseno University Botanic garden. In addition identification of contact farmers selected from those from which germplasm was collected. Distribution of $100 \mathrm{~g}$ of seed at the rate of two species per farmer and seed production packages were distributed in, Vihiga, Butere-Mumias (Luhya community), Kisumu, Siaya (Luo Community) Kisii, and Nyamira (Kisii community) districts between JanJune 2004. This was done with an aim of establishing seed support systems in those areas to ensure local availability of quality seed. After June 2004, a follow up was made to establish which of the contact farmers had succeeded in producing the seeds provided and as advised.

\section{Seed treatments for three African Leafy Vegetables in western Kenya}

A study was conducted between June and August 2004 at Maseno University in the Department of Botany and Horticulture laboratory and shade house. Seeds of Cleome gynandra, Corchorus olitorius and Solanum scabrum from the selected seed lots were first subjected to germination tests. These were selected on the basis that farmers in the three communities had identified them as species that normally have germination problems (table 1). Fifty (50) seeds of each vegetable were placed in a Petri dish lined

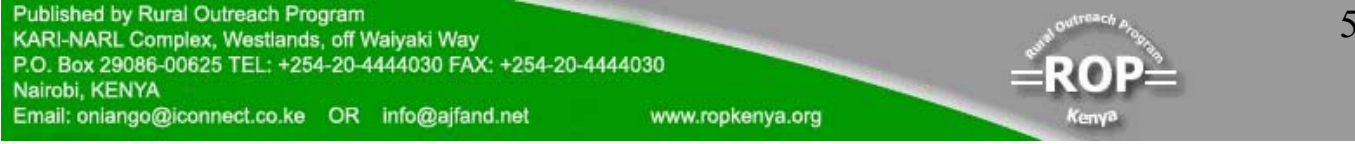


with a wetted filter paper and kept moist throughout the experiment replicated three times. Daily measurements on a number of germinated seeds were made and percentage germination was determined.

Plastic pots of $21 \mathrm{~cm}$ diameter and $21 \mathrm{~cm}$ height were filled with solarised sandy soil from Maseno University farm and shallowly sowed with 10 seeds of three African leafy vegetable species after subjecting them to various seed treatments. The experiment was set up in Completely Randomized Design with four treatments replicated three times. The treatments included $\mathrm{T}_{1}=$ No treatment or Control, $\mathrm{T}_{2}=$ Dipped seed in boiling water for 10 seconds, $\mathrm{T}_{3}=$ Soaked seeds in water for $24 \mathrm{hrs}$ and $\mathrm{T}_{4}=$ Soak seed in $95 \%$ acetone for 30 minutes. Parameters measured included, seedling emergence, plant height, number of leaves and leaf area at 15 days after sowing.

Data analysis for the surveys was done by using descriptive statistics and cross tabulation and calculating and presenting percentages in tables. Data from the laboratory and shade house study were analyzed statistically using analysis of variance (ANOVA) to establish if the treatment effects were significant at $5 \%, 1 \%$ or $0.1 \%$. Separation of means was done only for those parameters where the ANOVA was significant, using Least significant Difference at 5\% level (LSD $\mathrm{L}_{5 \%}$.).

\section{RESULTS}

\section{Current seed support and supply systems of African Leafy Vegetables in Luhya, Luo and Kisii Communities}

In Luhya, Luo and Kisii, communities women made up $80 \%, 95 \%$ and $50 \%$ of the respondents, respectively. Land parcels owned by farmers varied from $0.5-5$ hectares, 1.5-10 hectares and 0.5 -5 hectares for the Luhya,Luo and Kisii communities, respectively and the percentage of land allocated to African Leafy Vegetables varied from $5-30 \%$. All the respondents stated that they were growing the vegetables for both consumption and for sale. The most profitable African Leafy Vegetables were identified as spiderplant (Cleome gynandra), slenderleaf (Crotalaria spp) African nightshade (Solanum spp), Cowpea (Vigna unguiculata), Vegetable amaranths (Amaranthus blitum) and jute mallow (Corchorus olitorius) starting with the highly profitable ones. Table 1 shows percentage of farmers' responses on various aspects of seed support systems for African Leafy Vegetables.

Most of the farmers preferred to produce their own seed (94\%) and/or purchase them from the village market $(72 \%)$ than to source from other places. The main mechanisms of distributing seed was by selling $(29 \%)$ or given out as a gift $(21 \%)$. Over $50 \%$ of the respondents did not participate in distribution of seed of African Leafy Vegetables.

Eighty percent $(80 \%)$ of the households interviewed process seed on their farms either by dry $(92 \%)$ and/or by use of wet $(71 \%)$ processing methods. Seed selection was normally done either randomly $(19 \%)$, choosing healthy plants $(56 \%)$ or by maturity

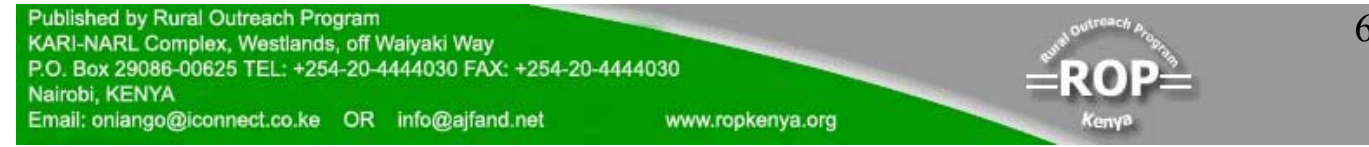


$(24 \%)$ of pods. Seed storage was done in plastic pot after treatment with wood ash $(63 \%)$, in tins with wood ash $(27 \%)$, in bottles with wood ash $(9 \%)$ or in polythene bags with wood ash (2\%). In this form, seed would store for a period of 6-24 months depending on the species or prevailing environmental conditions.

\section{Germplasm Collection, Evaluation and Multiplication of Priority African Leafy Vegetables in Western Kenya}

Germplasm collection and evaluation of seven African Leafy Vegetables from three communities are shown in the table 2. A total of 42 accessions were collected as follows seven (7) vegetable species (2) seed lots per species for each of the three (3) communities. The selected accessions for each vegetable species based on the weight, germination \% and moisture content are also shown in table 2. Except for spiderplant (Cleome gynandra) and African nightshade (Solanum scabrum) laboratory germination was high $(>70 \%)$ and correlated very well with field germination $(>80 \%)$. The selected accessions were to have a weight of not less than $15 \mathrm{~g}$ per accession to allow for multiplication while the other accessions with lower seed weight were discarded. Moisture content for all the accessions ranged between 9.5 and $11.2 \%$.

The results of the seed yields of the multiplied germplasm are shown in table 3 .

Seed yields per hectare varied slightly with the vegetable species but ranged from 1036 (Corchorus olitorius) to 1320 (Amaranthus blitum) kg/ha. The 1000 seed weight of the seven species was also determined and this also varied with species as shown in table 3. Cleome gynandra, Solanum scabrum, Corchorus olitorius and Amararanthus blitum had 1000 seed weights of $1.4,1.2,1.9$ and $1.1 \mathrm{~g}$ respectively. Crotalaria brevidens had 1000 seed weight of 5.8g and Crotalaria ochroleuca had 5.6g while and Vigna unguiculata had 1000 seed weight of $100 \mathrm{~g}$.

\section{Setting up seed support systems}

A seed support system was set up at Maseno University Botanic garden where seed of the seven selected species were produced during the long and short rains each subsequent year after the study to support the already existing seed support systems like Rural Outreach Program. Optimal appropriate seed processing is done and seed tested for moisture content and germination percentage and packed in 10, 20,50 or $100 \mathrm{~kg}$ plastic bags and sealed ready for distribution. These seeds are available throughout the year.

A total of 70 farmers in 6 districts were provided with seed and technical information on the production and seed processing of seven African Leafy Vegetables, with community distribution of 25, 29 and 16 for the Luo, Luhya and Kisii communities, respectively as shown in table 4 . Table 5 shows the follow-up made on 9 farmers representing only $13 \%$ of the total number of contact farmers that were given seeds. Eighty percent $(80 \%)$ of the monitored farmers were women. All the farmers visited

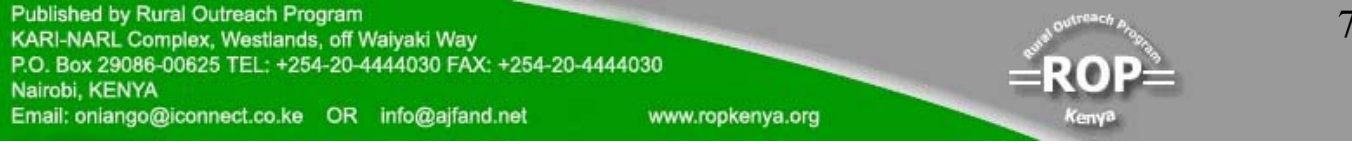




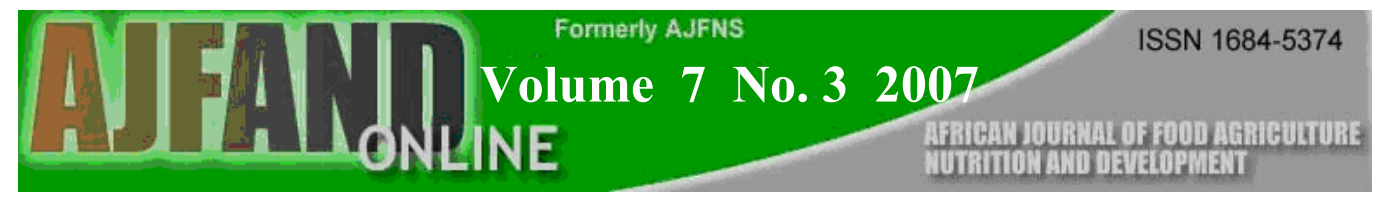

were producing their own seed and $22 \%$ of them were selling the surplus to the village market and were all women.

\section{Seed treatments for three African Leafy Vegetables in western Kenya}

Laboratory germination percentages for spiderplant, scabrum nightshades and jute mallow were 20, 28 and $86 \%$, respectively. Table 6 shows the seedling emergence of the three species of African Leafy Vegetables at 15 days after sowing. Results indicate that seed treatment significantly $(\mathrm{p} \leq 0.05)$ affected seedling emergence of spiderplant (Cleome gynandra) and African nightshade (Solanum scabrum) but had no significant $(\mathrm{p}>0.05)$ effect on jute mallow (Corchorus olitorius). Seeds of both spiderplant and nightshades that were not treated had significantly lower seedling emergence than those soaked in water for 24 hours and those soaked in $95 \%$ acetone. Treatment effects on plant height, number of leaves and leaf area per plant were not significant $(p>0.05)$ at 15 days after sowing for all the three species.

\section{DISCUSSION}

\section{Current seed support and supply systems of African Leafy Vegetables in Luhya, Luo and Kisii communities}

In many communities in Kenya especially the western part, the growing, processing and marketing of leafy vegetables is normally done by women $[1,10]$. The results from this study showed that, this was the case for Luhya and Luo communities but not for the Kisii community, where gender distribution was 50\%.

This observation in Kisii district could be attributed to the fact that as a crop develops from subsistence status to a commercial commodity men tend to become more involved [4] as is the case of ALVs in Kisii district. Priority African Leafy Vegetables identified in this study that included Cleome gynandra, Crotalaria spp Solanum spp, Vigna unguiculata, Amaranthus blitum and Corchorus olitorius agrees with reports of other workers who identified same ALVs species as priority in western Kenya in terms of production, consumption and marketability $[1,4]$. These vegetables have been reported to be highly nutritious containing $100 \%$ of the recommended daily allowance for vitamin $\mathrm{A}$ and $\mathrm{C}$, iron and calcium and $40 \%$ for protein in their fresh leaves [11].

The identified species also have medicinal properties and mature very fast, producing seed under tropical conditions unlike the temperate species $[3,12]$. Their ability to withstand drought, low soil fertility and pests and diseases makes them popular with the resource poor farmers. Because of their many advantages, these vegetables should be improved so that they develop into commercial crop for both the local and export markets to help alleviate poverty and improve the food and nutrition situation of communities in the study areas.

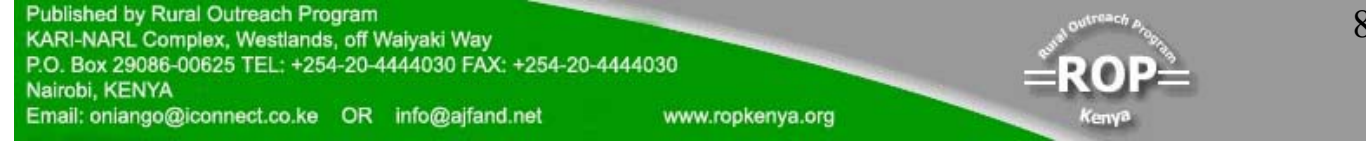


Commercialization should focus on both leaf and seed production. In most cases no proper selection is conducted to choose the best plants and fruits for seed production on farmers fields [6] ,which agrees with our finding that some farmers just picked seed at random. No community disparities were observed in this study with regard to source of seed, distribution, seed processing and storage, longevity of seed and seeds with germination problems. As has been reported by other workers, ALVs are still largely subsistence and deliberate efforts have to be made to commercialize them $[3,4$ \& 14].

\section{Germplasm collection, evaluation and multiplication of priority African Leafy Vegetables in three communities of western Kenya}

Laboratory germination for the selected germplasm ranged from $30 \%$ to $100 \%$ and except for Cleome gynandra and Solanum scabrum, the laboratory germination correlated very well with the field germination. It has been advanced that the differences between laboratory and field germination could possibly be due to photo inhibition that has been observed in spiderplant [8]. Spiderplant and nightshades with laboratory germination of $30 \%$ and $50 \%$, respectively have been reported to have inherent dormancy problems especially if the seeds were not properly harvested and processed $[3,12]$ and low germination of $15 \%$ (spiderplant) and 5.3\% (African nightshade) from farmers' fields have been reported [13] .

Photo-inhibition of spiderplant seeds has been reported to occur as temperature progressively decreased and was evident at $20^{\circ} \mathrm{C}$ [8] during this inhibition the seeds are not able to germinate as they are in a state of suspended germination. Moisture content did not vary significantly within and between species where the observed range was from $11-12.5 \%$. Moisture content of seed has a great influence on seed viability and seedling vigour, where for small seeds moisture content of 5-10\% is optimal, while for larger seeds it is $11-14 \%$ moisture for longer storage and maintenance of quality $[12,14]$.

Seed yields and quality of African Leafy Vegetables will depend not only on the management of the crop in the field but also on the harvesting and processing of the seed [7]. Seed yields of $500-900 \mathrm{~kg} /$ ha for spiderplant, African nightshades, jute mallow, slenderleaf and vegetable amaranths have been reported in Kenya [7, 13]

\section{Setting up seed support systems}

Success of a crop is determined by use of quality seed, and for African Leafy Vegetables quality seed production technology at farmers' own field is a basic input and primary pre-requisite for vegetable growing [5, 6].Although, this did not come out directly from this study, but from published sources of secondary information there are indications of the existence of ALVs seed support initiatives that are operating in the three communities studied. 
Seed production at the farm level by farmers is still the most common source of seeds for African leafy vegetable farmers in western Kenya and more often than not, seeds produced are of poor quality $[2,5,6]$ and some of the initiatives are addressing the problem of poor seed quality for ALVs. Under the Soil Management Project (SMP) and Integrated Pest Management (IPM) concepts for seed production, more than 500 farmers in Kisii district are participating in Cleome gynanda and Solanum villosum seed production as an alternative way for income generation [6].

Another seed production initiative is by a community based organization in Siaya district, where Technology Adoption Through Research Organization (TATRO) is committed to this venture after receiving training from national and international research organizations on growing and seed processing of African Leafy Vegetables [5]. TATRO is involved in and committed to seed production, processing, storage and distribution of Cleome gynandra, Crotalaria brevidens, Crotalaria ochroleuca, Corchorus olitorius and Solanum scabrum. Although there was no direct response from farmers on the existing seed support initiatives in the study area, such initiatives do exist.

The initiatives include Rural Outreach Programme (ROP) in Butere/Mumias district, an initiative that is involved in the production, processing and distribution of Cleome gynandra, Crotalaria brevidens, Crotalaria ochroleuca, Corchorus olitorius, Amaranthus blitum, Brassica carinata, Cucurbita moschata and Solanum scabrum seed to the farmers in the district and its environs. Efforts of this study and seed support system at Maseno University Botanic garden collaborate with and comple ments the existing initiatives in the three communities. There is a great need to increase and strengthen African leafy vegetable seed support systems at the farm, village, community, institutional, national and regional level.

\section{Seed treatments for three African Leafy Vegetables in western Kenya}

Spiderplant (Cleome gynandra), African nightshades (Solanum scabrum) and Jute mallow (Corchorus olitorius) were identified to have dormancy problems in this study and this observation agrees with the report that germination of spiderplant, nightshades and jute mallow is usually uneven due to seed dormancy [3]. Seed treatments had no significant effect on the seedling emergency of jute mallow. Fresh and sometimes old jute mallow seeds show dormancy caused by impermeability of seed coat and to suppress the dormancy, it is recommended that seed is tied in a piece of clothe and immersed for 5 seconds in almost boiling water or scarifying with sand paper [15].

Germination percentages observed do not agree with what is reported in literature [8, 9] and there may be other physiological aspects that could be contributing to the dormancy besides the physical hardness of the seed coat. In spider-plant, dormancy is much reduced with time and this could be due to reduction of growth inhibitors [16].

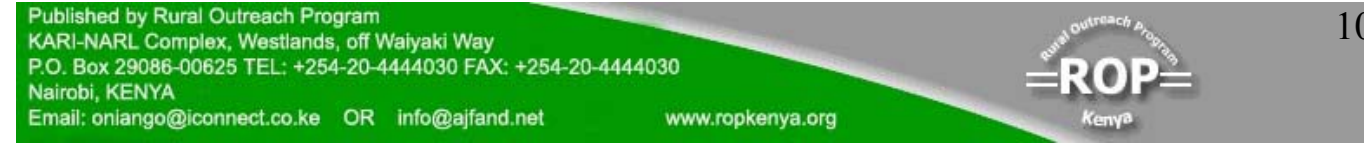


For African nightshades low germination is caused by improper seed extraction and therefore inadequate removal of sugars and germination inhibitors present in the fruit [17]. It is therefore understandable that the soaking treatments enhanced seedling emergence possibly by their effect on the leaching out germination or growth inhibitors in the seed. The low seedling emergence in the parboiled treatment in all the three species could be explained by the fact that, there is a possibility of killing the embryo during the process [8].

\section{CONCLUSIONS}

The current seed support systems for African Leafy Vegetables in the three communities studied were informal and constituted mainly production from farmers' own farms $(94 \%)$ or from the village market $(72 \%)$ although the existence of seed support system initiatives like Rural Outreach program and TATRO were noted

Germplasm of Seven Priority African leafy vegetable species was collected from three communities in Western Kenya, evaluated and multiplied. The identified and selected priority species included: Amaranthus blitum, Cleome gynandra, Corchorus olitorius, Crotalaria brevidens, Crotalaria ochroleuca, Solanum scabrum and Vigna unguiculata based on seed weight, ger mination percentage and moisture content.

A total of 70 contact farmers in 6 districts of western Kenya were provided with seed and technical information on production and processing of seed, 13\% of whom were already producing quality seed for their own use or sale. A seed support system was set up at Maseno University Botanic garden to avail seed of the seven African Leafy Vegetables to farmers this was to complement the already existing initiatives like Technology Adoption Through Research Organization(TATRO) and Rural Outreach Programme (ROP).

Seed treatment significantly increased seedling emergence of spiderplant and African nightshade but had no effect on jute mallow.

\section{ACKNOWLEDGEMENT}

The author is grateful to IPGRI African Leafy Vegetables Programme for funding the study and Maseno University for providing the facilities and giving logistical and institutional support. Patrick Omulubi and Peter Olewe for assisting in the administration of the questionnaires, germplasm collection and evaluation in the laboratory and field, and seed multiplication. 


\section{TABLES}

Table 1: Farmers' response (\%) on seed support systems for African Leafy Vegetables in three communities in western Kenya

\begin{tabular}{|l|l|l|l|l|}
\hline Practice & Luhya & Luo & Kisii & Mean \\
\hline *Source of seed (\%) not & & & & \\
mutually exclusive & & & & \\
Own seed & 82 & 100 & 100 & $\mathbf{9 4}$ \\
Village market & 86 & 100 & 30 & $\mathbf{7 2}$ \\
Outside village & 10 & 0 & 0 & $\mathbf{3}$ \\
\hline Distribution & & & & \\
Sell & 21 & 15 & 50 & $\mathbf{2 9}$ \\
Gift & 19 & 25 & 10 & $\mathbf{1 8}$ \\
None & 60 & 60 & 40 & $\mathbf{5 3}$ \\
& & & & \\
\hline Seed selection & & & & \\
Random & 21 & 12 & 25 & $\mathbf{1 9}$ \\
Healthy & 54 & 65 & 50 & $\mathbf{5 6}$ \\
Maturity & 25 & 23 & 25 & $\mathbf{2 5}$ \\
\hline *Seed processing & $\mathbf{7 4}$ & $\mathbf{7 6}$ & $\mathbf{8 6}$ & $\mathbf{8 0}$ \\
Sundry, thresh and winnow & 75 & 100 & 100 & $\mathbf{9 2}$ \\
Squeeze and sundry & 50 & 80 & 44 & $\mathbf{5 8}$ \\
Squeeze and dry in shade & 0 & 0 & 40 & $\mathbf{1 3}$ \\
\hline Seed storage method & & & & \\
Bottle with wood ash & 12 & 0 & 6 & $\mathbf{9}$ \\
Plastic pot with wood ash & 54 & 65 & 70 & $\mathbf{6 3}$ \\
Tins with wood ash & 34 & 35 & 12 & $\mathbf{2 7}$ \\
Polythene with wood ash & 0 & 0 & 6 & $\mathbf{2}$ \\
\hline Longevity of seed & 10 & 20 & 0 & $\mathbf{1 0}$ \\
6 months & 54 & 64 & 50 & $\mathbf{5 6}$ \\
1 year & 20 & 10 & 20 & $\mathbf{2 0}$ \\
2years germination & 16 & 6 & 30 & $\mathbf{1 4}$ \\
not known & 12 & & & \\
\hline Seeds with & & & \\
problems & 70 & 45 & 00 & $\mathbf{1 8}$ \\
African nightshade & 18 & 35 & & \\
Spiderplant & & & & \\
Jute mallow & & & & \\
& & & & \\
\hline
\end{tabular}

*percentages not mutually exclusive 
Table 2: Selected accessions from a total of 42 of African Leafy Vegetables from Western Kenya

\begin{tabular}{|l|l|l|l|l|l|}
\hline ALVs & $\begin{array}{l}\text { Collection } \\
\text { number }\end{array}$ & $\begin{array}{l}\text { Weight } \\
\text { (g) }\end{array}$ & $\begin{array}{l}\text { \%Germination } \\
\text { Lab }\end{array}$ & $\begin{array}{l}\text { \%Germination } \\
\text { Field }\end{array}$ & $\begin{array}{l}\text { Moisture } \\
\text { content\% }\end{array}$ \\
\hline $\begin{array}{l}\text { Cleome } \\
\text { gynandra }\end{array}$ & $\mathbf{7}$ & $\mathbf{4 0 . 6}$ & $\mathbf{3 0}$ & $\mathbf{9 0}$ & $\mathbf{1 1 . 2}$ \\
\hline $\begin{array}{l}\text { Solanum } \\
\text { scabrum }\end{array}$ & $\mathbf{3 4}$ & $\mathbf{1 5 . 6}$ & $\mathbf{5 0}$ & $\mathbf{8 5}$ & $\mathbf{1 1 . 0}$ \\
\hline $\begin{array}{l}\text { Corchorus } \\
\text { olitorius }\end{array}$ & $\mathbf{1 3}$ & $\mathbf{2 2 . 1}$ & $\mathbf{7 5}$ & $\mathbf{8 0}$ & $\mathbf{1 0 . 2}$ \\
\hline $\begin{array}{l}\text { Crotalaria } \\
\text { brevidens }\end{array}$ & $\mathbf{8}$ & $\mathbf{2 0 . 8}$ & $\mathbf{1 0 0}$ & $\mathbf{9 5}$ & $\mathbf{9 . 5}$ \\
\hline $\begin{array}{l}\text { Crotalaria } \\
\text { ochroleuca }\end{array}$ & $\mathbf{1 0}$ & $\mathbf{2 2 . 3}$ & $\mathbf{1 0 0}$ & $\mathbf{9 9}$ & $\mathbf{9 . 5}$ \\
\hline $\begin{array}{l}\text { Amaranthus } \\
\text { blitum }\end{array}$ & $\mathbf{2 2}$ & $\mathbf{3 4 . 0}$ & $\mathbf{8 5}$ & $\mathbf{8 6}$ & $\mathbf{9 . 6}$ \\
\hline $\begin{array}{l}\text { Vigna } \\
\text { unguiculata }\end{array}$ & $\mathbf{2}$ & $\mathbf{3 0 . 7}$ & $\mathbf{1 0 0}$ & $\mathbf{9 0}$ & $\mathbf{1 0 . 9}$ \\
\hline
\end{tabular}

Table 3: Seed yields of seven African Leafy Vegetables

\begin{tabular}{|l|l|l|}
\hline Vegetable & Yield (kg/ha) & $\mathbf{1 0 0 0}$ seed weight (g) \\
\hline Cleome gynandra & 1100 & 1.4 \\
\hline Solanum scabrum & 1124 & 1.2 \\
\hline Corchorus olitorius & 1036 & 1.9 \\
\hline Crotalaria brevidens & 1272 & 5.8 \\
\hline Crotalaria ochroleuca & 1172 & 5.6 \\
\hline Amaranthus blitum & 1320 & 1.1 \\
\hline Vigna unguiculata & 1120 & 100 \\
\hline
\end{tabular}

Table 4: Seed distribution and technical advice and outreach on African Leafy Vegetablesa ( given $50 \mathrm{~g}$ of seed of their choice and technical leaflets in Kiswahili or English)

\begin{tabular}{|c|c|c|c|}
\hline $\begin{array}{l}\text { District/Comm } \\
\text { represented }\end{array}$ & & $\begin{array}{l}\text { Number of farmers } \\
\text { /groups } \\
\text { Per district }\end{array}$ & $\begin{array}{l}\text { Number } \\
\text { community }\end{array}$ \\
\hline Kisumu & -Luo & 14 & \multirow[t]{2}{*}{25} \\
\hline Siaya & -Luo & 11 & \\
\hline Vihiga & -Luhya & 24 & \multirow[t]{2}{*}{29} \\
\hline Butere-Mumias & -Luhya & 05 & \\
\hline Kisii & -Kisii & 11 & \multirow[t]{2}{*}{16} \\
\hline Nyamira & -Kisii & 05 & \\
\hline
\end{tabular}




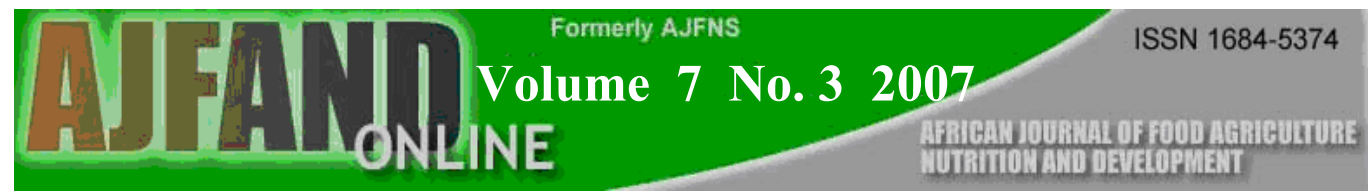

\begin{tabular}{|l|l|l|}
\hline Total & $\mathbf{7 0}$ & $\mathbf{7 0}$ \\
\hline
\end{tabular}

Table 5: Follow up of farmers given seed done between 10/10/2004 and11/10/2004

\begin{tabular}{|c|c|c|c|c|}
\hline District & $\begin{array}{l}\text { Number } \\
\text { given seed }\end{array}$ & $\begin{array}{l}\text { Number } \\
\text { followed }\end{array}$ & Gender & Comments \\
\hline Kisumu & 14 & 2 & FF & $\begin{array}{l}\text { Both Produces own seeds } \\
(22 \%)\end{array}$ \\
\hline Siaya & 11 & - & - & \\
\hline Vihiga & 24 & 2 & MM & $\begin{array}{l}\text { Produce own seed, the other } \\
\text { gets from neighbours }(22 \%)\end{array}$ \\
\hline Butere-Mumias & 05 & 2 & $\mathrm{FF}$ & $\begin{array}{l}\text { Both farmers produces own } \\
\text { seed and even sells the } \\
\text { surplus-gave us samples } \\
(22 \%)\end{array}$ \\
\hline Kisii & 11 & 1 & $\mathrm{~F}$ & Produces own seed $(12 \%)$ \\
\hline Nyamira & 05 & 2 & $\mathrm{FF}$ & Produces own seed (22\%) \\
\hline Total & 70 & $9(13 \%)$ & $80 \% F$ & \\
\hline
\end{tabular}

Table 6: Effect of seed treatment on percentage seedling emergence of three African Leafy Vegetables 15 days after sowing

\begin{tabular}{|l|l|l|l|}
\hline Treatments & Spiderplant & Nightshades & Jute mallow \\
\hline $\mathrm{T}_{1}$ & $\mathbf{2 7}$ & $\mathbf{3 3}$ & $\mathbf{8 8}$ \\
\hline $\mathrm{T}_{2}$ & $\mathbf{4 5}$ & $\mathbf{5 6}$ & $\mathbf{7 7}$ \\
\hline $\mathrm{T}_{3}$ & $\mathbf{7 2}$ & $\mathbf{7 4}$ & $\mathbf{8 8}$ \\
\hline $\mathrm{T}_{4}$ & $\mathbf{7 6}$ & $\mathbf{8 2}$ & $\mathbf{9 4}$ \\
\hline LSD $_{\mathbf{5} \%}$ & $\mathbf{1 0}$ & $\mathbf{9 *}$ & $\mathbf{n s}$ \\
\hline
\end{tabular}

$\mathrm{T}_{1}=$ No treatment or Control, $\mathrm{T}_{2}=$ Dipped seed in boiling water for 10 seconds, $\mathrm{T}_{3}=$ Soaked seeds in water for $24 \mathrm{hrs}$ and $\mathrm{T}_{4}=$ Soak seed in $95 \%$ acetone for 30 minutes 


\section{REFERENCES}

1. Abukutsa-Onyango MO Market survey on African indigenous vegetables in western Kenya. In: JM Wesonga T Losenge CK Ndung'u, K.Ngamau, JBM Njoroge, FK Ombwara, SG Agong, A Fricke, B Hau and H Stutzel (Eds) Proceedings of the second Horticulture seminar on Sustainable Horticultural production in the tropics. JKUAT 2002: 39-46.

2. Ndinya C Seed production and supply system of three African Leafy Vegetables in Kakamega District. In: MO Abukutsa-Onyango AN Muriithi VE Anjichi K Ngamau SG Agong A Fricke B Hau and H Stutzel (Eds). Proceedings of the third Horticulture Workshop on Sustainable Horticultural production in the Tropics. Maseno University, Masono 2005:60-67.

3. Schippers RR African indigenous vegetables: an overview of the cultivated species. Chatham, UK. Natural Resources Institute /ACP-EU Technical Centre for Agricultural and rural Cooperation.2002.

4. Chweya JA and PB Eyzaguire (Eds) The biodiversity of traditional Leafy vegetables. International Plant Genetic Resources Institute, Rome, Italy, 1999.

5. Okong'o P Community seed production of African indigenous vegetables. In: MO Abukutsa-Onyango AN Muriithi VE Anjichi K Ngamau SG Agong A Fricke B Hau and H Stutzel (Eds) Proceedings of the third Horticulture Workshop on Sustainable Horticultural production in the Tropics. Maseno University, Maseno 2005:59-60.

6. Ngoze $\mathbf{S}$ and $\mathbf{N}$ Okoko On farm seed production in Kisii district: An overview of resent situation. In: MO Abukutsa-Onyango AN Muriithi VE Anjichi K Ngamau SG Agong A Fricke B Hau and H Stutzel (Eds) Proceedings of the third Horticulture Workshop on Sustainable Horticultural production in the Tropics. Maseno University, Maseno 2005:33-37.

7. K'opondo FBO, Muasya RM and OK Kiplagat A review on the seed production and handling of indigenous vegetables (spiderplant, jute mallow and African nightshade complex) In: MO Abukutsa-Onyango AN Muriithi VE Anjichi K Ngamau SG Agong A Fricke B Hau and H Stutzel (Eds) Proceedings of the third Horticulture Workshop on Sustainable Horticultural production in the Tropics. Maseno University, Maseno 2005:42-48.

8. Ochuodho JO, Modi AT and M Beukes The dormancy and germination of Cleome gynandra L. In: JM Wesonga (Eds) Proceedings of the fourth workshop on Sustainable Horticultural production in the tropics. Moi University, Eldoret 2005:227-242. 
9. Abukutsa-Onyango MO Effect of nitrogen rates on germination of stored seed of slenderleaf (Crotalaria brevidens) In: JM Wesonga (Eds) Proceedings of the fourth workshop on Sustainable Horticultural production in the tropics. Moi University, Eldoret 2005:188-195.

10. Maundu PM The status of traditional vegetable utilization in Kenya. In: L Guarino (Ed). Proceedings of the IPGRI International workshop on genetic resources of traditional vegetables in Africa: Conservation and use. ICRAFHQ, Nairobi, Kenya 1997:66-75.

11. Chweya JA Identification and nutritional importance of indigenous green leaf vegetables in Kenya. Acta Hort. 1985; 153:99-108.

12. Mwai GN, Onyango JC and MO Abukutsa-Onyango Potential salinity resistance in spiderplant (Cleome gynandra L.). African Journal of Food, Aagriculture, Nutrition and Development (AJFAND) 2005 .Online journal. www.ajfand.net 4:2.

13. Kamotho GN, Muasya RM, Mathenge PW and M Dulloo Effects of packaging and storage conditions on seed quality of Cleome gynandra L. In: MO Abukutsa-Onyango AN Muriithi VE Anjichi K Ngamau SG Agong A Fricke B Hau and H Stutzel (Eds) Proceedings of the third Horticulture Workshop on Sustainable Horticultural production in the Tropics. Maseno University, Maseno 2005:67-73.

14. Abukutsa-Onyango MO Unexploited potential of indigenous African indigenous vegetables in western Kenya. Maseno Journal of Education, Arts and Science 2003; 4:103-122.

15. Fondio L and GJH Grubben Corchorus olitorius In: GJH Grubben \& OA Denton (Eds). Plant Resources of Tropical Africa 2.Vegetables. PROTA Foundation, Wageningen, Netherlands/Backhuys Publishers, Leiden,:217-221.

16. Mnzava NA and F Chigumira Cleome gynandra L In: GJH Grubben \& OA Denton (Eds). Plant Resources of Tropical Africa 2.Vegetables. PROTA Foundation, Wageningen, Netherlands/Backhuys Publishers, Leiden, Netherlands/CTA, Wageningen, Netherlands 2004:191-195.

17. Fontem DA and RR Schippers Solanum scabrum In:GJH Grubben \& OA Denton (Eds). Plant Resources of Tropical Africa 2.Vegetables. PROTA Foundation, Wageningen, Netherlands/Backhuys Publishers, Leiden, Netherlands/CTA, Wageningen, Netherlands 2004:493-498. 